\title{
Optimization of Sulfide/Sulfite Pretreatment of Lignocellulosic Biomass for Lactic Acid Production
}

\author{
Muhammad Idrees, ${ }^{1}$ Ahmad Adnan, ${ }^{1}$ and Fahim Ashraf Qureshi ${ }^{2}$ \\ ${ }^{1}$ Department of Chemistry, GC University, Katchery Road, Lahore 54000, Pakistan \\ ${ }^{2}$ Office of Research, Innovation and Commercialization, COMSATS Institute of Information Technology, Chak Shahzad, Park Road, \\ Islamabad 45600, Pakistan \\ Correspondence should be addressed to Fahim Ashraf Qureshi; qureshifa@comsats.edu.pk
}

Received 25 March 2013; Revised 24 June 2013; Accepted 24 June 2013

Academic Editor: Alain Dufresne

Copyright ( 2013 Muhammad Idrees et al. This is an open access article distributed under the Creative Commons Attribution License, which permits unrestricted use, distribution, and reproduction in any medium, provided the original work is properly cited.

Potential of sodium sulfide and sodium sulfite, in the presence of sodium hydroxide was investigated to pretreat the corncob (CC), bagasse (BG), water hyacinth and rice husk (RH) for maximum digestibility. Response Surface Methodology was employed for the optimization of pretreatment factors such as temperature, time and concentration of $\mathrm{Na}_{2} \mathrm{~S}$ and $\mathrm{Na}_{2} \mathrm{SO}_{3}$, which had high coefficient of determination $\left(R^{2}\right)$ along with low probability value $(P)$, indicating the reliable predictability of the model. At optimized conditions, $\mathrm{Na}_{2} \mathrm{~S}$ and $\mathrm{Na}_{2} \mathrm{SO}_{3}$ remove up to $97 \%$ lignin, from $\mathrm{WH}$ and $\mathrm{RH}$, along with removal of hemicellulose (up to 93\%) during pretreatment providing maximum cellulose, while in BG and CC; $75.0 \%$ and $90.0 \%$ reduction in lignin and hemicellulose was observed. Saccharification efficiency of RH, WH, BG and CC after treatment with $1.0 \% \mathrm{Na}_{2} \mathrm{~S}$ at $130^{\circ} \mathrm{C}$ for $2.3-3.0 \mathrm{~h}$ was 79.40 , $85.93,87.70$, and $88.43 \%$, respectively. WH treated with $\mathrm{Na}_{2} \mathrm{SO}_{3}$ showed higher hydrolysis yield (86.34\%) as compared to $\mathrm{Na}_{2} \mathrm{~S}$ while other biomass substrates showed 2.0-3.0\% less yield with $\mathrm{Na}_{2} \mathrm{SO}_{3}$. Resulting sugars were evaluated as substrate for lactic acid production, yielding $26.48,25.36,31.73$, and $30.31 \mathrm{gL}^{-1}$ of lactic acid with 76.0, 76.0, 86.0, and 83.0\% conversion yield from CC, BG, $\mathrm{WH}$, and RH hydrolyzate, respectively.

\section{Introduction}

Conventional substrates such as starch or sucrose are not available in large quantities with affordable prices for the production of industrial chemicals [1]. Lignocellulosic materials are attractive alternatives due to being easily available in large quantities at low price all over the world [2, 3]. They include agricultural residues (corn stover, bagasse, and rice husk), forestry residues (sawdust), portions of municipal solid wastes (waste paper), herbs and shrubs (switchgrass and water hyacinth), woody plants (poplar trees), and various industrial wastes [4]. Agricultural residues such as corncob, bagasse, and rice husk represent large renewable assets for lignocellulosic biomass [5]. According to the Food and Agriculture Organization of the United Nations, worldwide annual production of corn is about $695 * 10^{9} \mathrm{Kg}$, having $18 \%$ corncob [6], available as renewable raw material [7]. Corn is a major food crop after wheat and rice in Pakistan with annual production of $3760 \times 1000$ MT during year 2010-2011 [8]. Bagasse obtained after juice extraction consists of $40.0 \%-$ $50.0 \%$ cellulose, $25.0 \%$ hemicellulose, and $20.0 \%$ lignin, which could be converted into fermentable sugars. In Southeast Asia, 216 million ton agricultural biomass comprises of rice [9] which has $20.0 \%$ of rice husk [10]. Transformation of these agricultural byproducts into fermentable sugars and finally into lactic acids is desirable. Lactic acid has the best rudiments to become an intermediary product because its functional groups make it prone to further reactions, for example, the production of propionic acid, acetic acid, acrylic acid, alanine acid, or pyruvic acid [11].

The conversion of lignocellulosic materials into fermentable sugars usually includes high temperature (100$200^{\circ} \mathrm{C}$ ) with or without use of chemicals, which leads to the production of compounds such as lignin, acetic acid, furfural, and 5-hydroxymethylfurfural $[12,13]$ that are toxic to microorganisms. Enzymatic hydrolysis is an interesting 
TABLE 1: Values of independent variables with coded levels during pretreatment steps.

\begin{tabular}{lccccccc}
\hline Factor & Name & Units & Type & Minimum & Maximum & \multicolumn{2}{c}{ Coded } \\
\hline$A$ & Catalyst conc. & $\%$ & Numeric & 1.00 & 3.00 & $-1.000=1.00$ & $1.000=3.00$ \\
$B$ & Time & $\mathrm{h}$ & Numeric & 1.00 & 3.00 & $-1.000=1.00$ & $1.000=3.00$ \\
$C$ & Temp. & ${ }^{\circ} \mathrm{C}$ & Numeric & 90.00 & 130.00 & $-1.000=90.00$ & $1.000=130.00$ \\
\hline
\end{tabular}

way to produce sugars from cellulosic wastes because it requires mild operating conditions such as $\mathrm{pH}$ and temperature, without production of byproducts $[14,15]$. It requires a pretreatment process due to the recalcitrant nature of lignocellulosic materials, making the carbohydrate more accessible to the hydrolytic enzymes. Various physical (mechanical irradiation, microwave irradiation, and pyrolysis), chemical (acids such as sulfuric acid, phosphoric acid, maleic acid; alkalis such as sodium hydroxide, ammonia, ammonium sulfite; organic solvents such as ethanol/butanol/benzenewater and different swelling agents, oxidation with hydrogen peroxide, ozone, and wet oxidation), physiochemical (steam explosion, carbon dioxide explosion, and ammonia fiber explosion), and biological pretreatment techniques have been proposed, but all of them differ due to a change in the nature of the biomass [16-18]. There are a need to optimize the pretreatment method by choosing a suitable chemical which will provide maximum enzymatic hydrolysis [19]. Traditional sulfide and sulfite pulping processes have been in industry practice with 100 years of experience, providing a lot of knowledge and process expertise [20]. Sulfite treatment decreases the crystallinity of the xylan and the cellulose [21$24]$ and increases the hydrophilicity of the lignin though sulfonation [20]. Sodium hydroxide treatment reduces the lignin content $60 \%-90 \%$ at varying concentrations (1\%-8\%) along with decreasing the crystallinity of the cellulose by disrupting the structural linkages and increasing the surface area for enzyme penetration [25-28]. For maximum digestibility of the agricultural residues into fermentable sugars, combined effect of $\mathrm{NaOH}$ and $\mathrm{Na}_{2} \mathrm{~S}$ or $\mathrm{Na}_{2} \mathrm{SO}_{3}$ could be a potential solution for the removal of lignin, depolymerization of xylan without degrading the cellulose.

This study focused on alkali-catalyzed sulfide and sulfite pretreatments in order to optimize the pretreatment conditions by using the response surface methodology. The objectives of this study were the following: (1) finds the suitable catalyst for pretreatment of biomass, (2) statistical determination of the optimized pretreatment conditions at the lowest catalyst concentrations (\%), pretreatment time, and temperature, and (3) lactic acid production from resulting sugar.

\section{Material and Method}

2.1. Chemicals and Biomass. All chemicals were of analytical grade and used without further purification. ACCELLERASE 1500 and OPTIMASH BG were obtained from Genencor International Inc. Corncob, bagasse, water hyacinth, and rice husk were collected from different areas in Pakistan during 2011. These biomass materials were chopped into small pieces $(1-2 \mathrm{~cm})$ and dried in a hot-air oven at $105^{\circ} \mathrm{C}$ for $6 \mathrm{~h}$. Finally, the cleaned and dried biomass materials were ground into powdered form separately. The dried powder material was reserved at room temperature for further work.

2.2. Optimization of Pretreatment Process. The catalyst $\left\{\mathrm{NaOH}(0.5 \%\right.$ in water $)$ catalyzed $\mathrm{Na}_{2} \mathrm{~S}$ or $\left.\mathrm{Na}_{2} \mathrm{SO}_{3}\right\}$ concentration $\left(X_{1}\right)$, time $\left(X_{2}\right)$ and temperature $\left(X_{3}\right)$ used for pretreatment were optimized by using central composite design experiment to enhance the enzymatic hydrolysis yield. The design matrix with eighteen experimental runs in two blocks with four replicates of the midpoint was used. Twenty-five grams of each substrate (CC, BG, RH, and $\mathrm{WH}$ ) powder was mixed with predefined catalyst solution at $1: 10(\mathrm{w} / \mathrm{v})$ ratio in $500 \mathrm{~mL}$ flask separately. The flasks were autoclaved (CL-40L) (ALP Co., Ltd., Tokyo Japan) at different temperatures $\left(90-130^{\circ} \mathrm{C}\right.$ at pressure $\left.0.13-0.2 \mathrm{MPa}\right)$ for different time intervals as defined through RSM. The solutions in flasks were cooled and neutralized to $\mathrm{pH}$ 5-6 using $5.0 \%$ sulfuric acid solution, and they then filtered with Whatman filter paper 1 . The residues were washed with distilled water for several times to remove the excess alkali or acid and dissolved byproducts that might inhibit the enzymes in subsequent hydrolysis. The residue was dried at $105^{\circ} \mathrm{C}$ for $20 \mathrm{~min}$. and weighed. Coded values of independent variable along with their minimum and maximum values are shown in Table 1 . The model, used to enhance the response by optimizing the pretreatment factors, was a second-order polynomial as follows:

$$
Y=\beta_{0}+\sum_{i=1}^{n} \beta_{i} X_{i}+\sum_{i=1}^{n} \beta_{i i} X_{i}^{2}+\sum_{i=1}^{n} \sum_{j=1}^{n} \beta_{i j} X_{i} X_{j}
$$

where $Y$ is the hydrolysis yield and $i, j$ are the linear and quadratic coefficients, respectively; $\beta_{0}$ is the regression coefficient, and $X_{1}-X_{3}$ are the coded factors under study. Regression analysis and estimation of the coefficients were performed using Design Expert Software 8.1.07.

2.3. Enzymatic Hydrolysis of Pretreated Materials and Lactic Acid Fermentation. Accellerase 1500 and Optimash BG were used for hydrolysis of the pretreated substrate as describe by Idrees et al. [29]. Lactobacillus acidophilus, a homofermentative, lactic acid producing bacteria [30] was used for the production of lactic acid from enzymatic hydrolyzate. Inoculum was prepared by transferring cells into $100 \mathrm{~mL}$ flask containing $50 \mathrm{~mL}$ of culture medium containing $10.0 \mathrm{~g} / \mathrm{L}$ yeast extract, $2.0 \mathrm{~g} / \mathrm{L}\left(\mathrm{NH}_{4}\right)_{2} \mathrm{HPO}_{4}, 0.10 \mathrm{~g} / \mathrm{L} \mathrm{MnSO}_{4}$ and $30.0 \mathrm{~g} / \mathrm{L}$ glucose, and it was subsequently incubated at $37^{\circ} \mathrm{C}$ for $12.0 \mathrm{~h}$ [31]. After two consecutive transfers to fresh medium, this was used to inoculate the fermentation medium. Cellulosic 
TABLE 2: Composition of biomass before pretreatment.

\begin{tabular}{lcccc}
\hline Components & Corncob (CC) & Bagasse (BG) & Water hyacinth (WH) & Rice husk (RH) \\
\hline Extractives (wt\% dry) & $6.98 \pm 0.57$ & $7.65 \pm 0.61$ & $17.59 \pm 0.82$ & $20.88 \pm 0.57$ \\
Hemicellulose (wt\% dry) & $43.42 \pm 1.45$ & $33.18 \pm 1.03$ & $42.29 \pm 1.38$ & $24.20 \pm 1.05$ \\
Lignin (wt\% dry) & $13.56 \pm 0.74$ & $18.30 \pm 0.78$ & $4.23 \pm 0.38$ & $20.23 \pm 0.74$ \\
Cellulose (wt\% dry) & $38.98 \pm 1.05$ & $41.29 \pm 1.41$ & $20.37 \pm 0.94$ & $33.58 \pm 0.94$ \\
\hline
\end{tabular}

Duplicate results.

hydrolyzates, obtained from enzymatic hydrolysis of each pretreated sample, were used for fermentation. The inoculum to solution ratio of $1: 20$ was used for fermentation purposes. Samples, for glucose and lactic acid analysis, were taken at specific intervals during $72.0 \mathrm{~h}$ fermentation process.

\subsection{Analysis of Biomass Components, Reducing Sugars and Lactic Acid}

2.4.1. Biomass Components. The amount of extractives was determined with acetone using the Soxhlet apparatus. Two grams of dried biomass was used with $120 \mathrm{~mL}$ acetone for extraction at $90^{\circ} \mathrm{C}$ for two hours. After extractions solvents were removed, and the remaining residues dried at $105^{\circ} \mathrm{C}$. From weight differences before and after the extraction, calculate the amount of the extractives $[32,33]$. The quantification of hemicellulose was done by heating 2.0 grams extractive free dried biomass samples for two hours at $80^{\circ} \mathrm{C}$ in $20.0 \mathrm{~mL}$ of $0.5 \mathrm{~mol}$ solution of sodium hydroxide. After that, they washed with deionized water for neutral $\mathrm{pH}(\mathrm{pH}=7)$ and dried to a constant weight. The differences in biomass weight are the amounts of the hemicellulose [32, 33]. To determine the amount of the lignin, 1.0-gram extractive-free biomass sample were added in $30.0 \mathrm{~mL}$ of $98 \%$ sulfuric acid and kept for twenty-four hour at ambient temperature, then boiled at $100^{\circ} \mathrm{C}$ for one hour. The mixtures were filtered, and the residues were washed with deionized water until complete removal of the sulfate ion. They were then dried to a constant weight which is the weight of the lignin $[32,33]$. The cellulose contents were calculated from differences in total weights and the amounts of the hemicellulose, lignin and extractives by assuming that these are the only components of the entire biomass [32-34].

2.4.2. Reducing Sugars. Reducing sugars were determined by using Ghose (1987) [35] method; 3, 5-dinitrosalicylic acid (DNS) was used as a coloring reagent, and the absorbance for each sample was recorded at $\lambda=546 \mathrm{~nm}$ with double-beam spectrophotometer (Cecil 7200). Identification of monosaccharide contents was determined with the help of thin-layer chromatography (TLC) in pretreated, enzymatic hydrolyzate and fermentation media [29]. Sugar yield was calculated on pretreated solid biomass used for enzymatic hydrolysis by using the following equation [36]:

$$
\begin{aligned}
& \text { sugar yield (\%) } \\
& =100\left(\frac{\text { sugar produced during hydrolysis }}{\text { gram of biomass feedstock }}\right) .
\end{aligned}
$$

2.4.3. Lactic Acid. Lactic acid was quantified with the help of HPLC (LC-20AT, Shimadzu) method used by Bai et al., 2000 [37]. Reverse-phase SMA-C18 column with size $4.6 \times 250 \mathrm{~mm}$ of SMT, coupled with a UV variable wavelength detector (SPD-M20A, Shimadzu) at $210 \mathrm{~nm}$, was employed. The elution was carried out with the help of $0.01 \mathrm{M}$ phosphoric acid having $\mathrm{pH} 2.5$ using an isocratic elution with a flow rate of $1 \mathrm{ml} / \mathrm{min}$ at room temperature. The lactic acid has retention time $\left(t_{R}\right)$ at $2.4 \mathrm{~min}$.

\section{Results and Discussion}

Feedstock with low lignin $(<20 \%)$ content was desirable for maximum hydrolysis yield. Corncob, bagasse, rice husk, and water hyacinth were used as lignocellulosic materials for production of fermentable sugars. Composition of these biomass sources is described in Table 2. Amount of cellulose in bagasse sample was higher $(41.0 \%$ dry wt. also reported by Sun et al., 2004) [38], as compared with that of water hyacinth which was only $20.39 \%[39,40]$. Water hyacinth has $42.29 \%$ hemicellulose which was less as compared with the $48.7 \%$ one reported by Magdum et al., 2012 [41] but it equal to the corncob [42] and greater than bagasse and rice husk. Cellulose content of corncob was $38.98 \%$ which was close to the results of Satimanont et al., 2012 [43] while rice husk shows 33.4\% cellulose which was $2 \%$ less to that reported by Ugheoke and Mamat 2012 [44]. Water hyacinth (WH) and rice husk (RH) have higher amount of extractives ( 20\%) as compared with corncob and bagasse ( $\sim 7 \%)$. Total amount of polysaccharide were in these substrates are $82.40>74.47>62.66>57.78 \%$ corresponding to corncob, bagasse, $\mathrm{WH}$, and $\mathrm{RH}$, respectively. WH has less lignin content $(4.23 \%)$ as compared to other substrates which range from $13 \%$ to $20 \%$ on dry-weight basis. Maximum hydrolysis of the biomass was achieved by two-step process, that is, pretreatment and enzymatic hydrolysis. The conditions chosen for pretreatment method will affect various substrates characteristics, which in turn, govern the susceptibility of the substrates to hydrolysis and the subsequent fermentation of the released sugars. So, a careful study was done to pretreat the lignocellulosic materials for maximum digestibility of the cellulose to fermentable sugars and finally fermentation into lactic acid and bioethanol. Schematic diagram of the process was shown in Figure 1.

3.1. Effect of Sodium Sulfide and Sulfite on the Biomass Weight Loss (Lignin and Hemicellulose Removal). The amount of cellulosic residue after pretreatment was found to be different for different catalysts at varying conditions (Figure 2). 


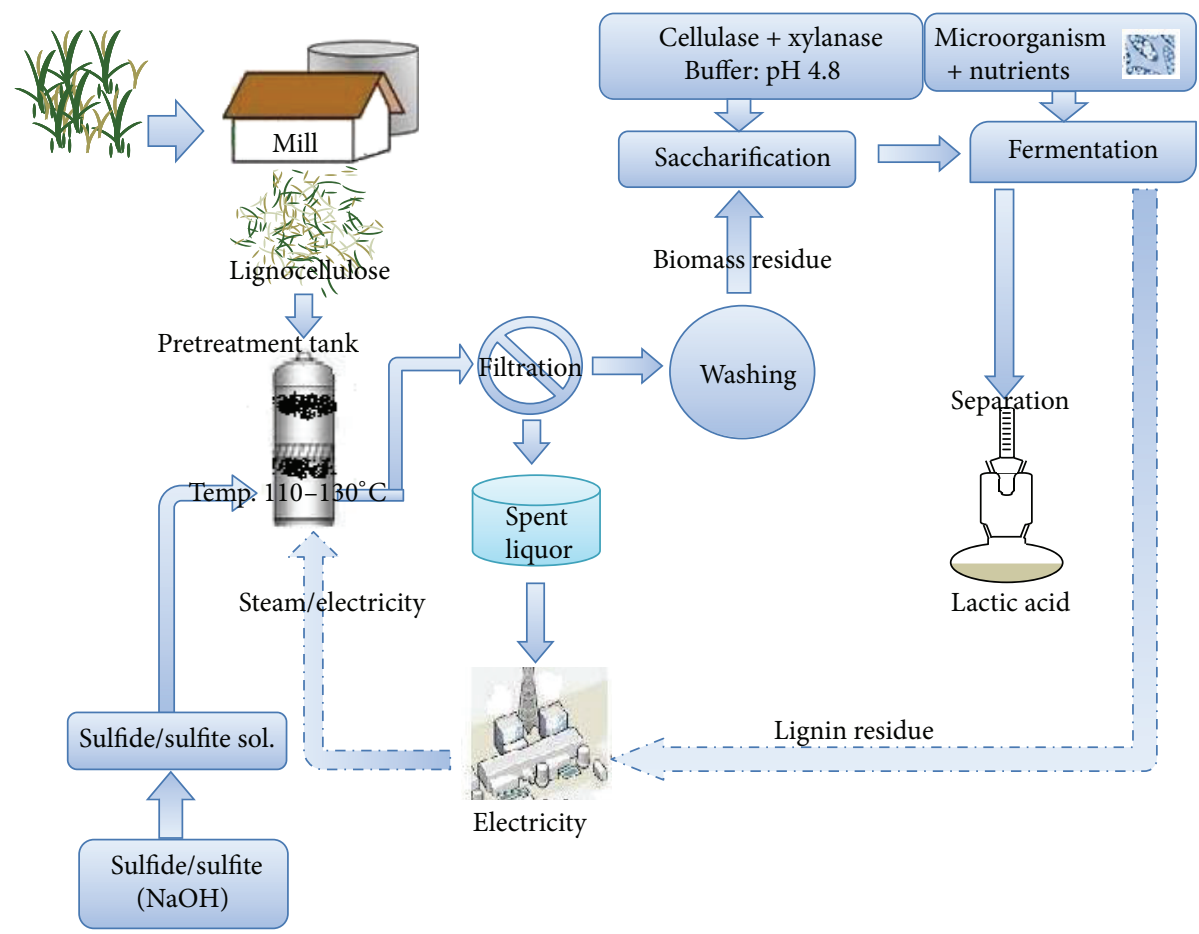

FIGURE 1: Flow diagram of the process.

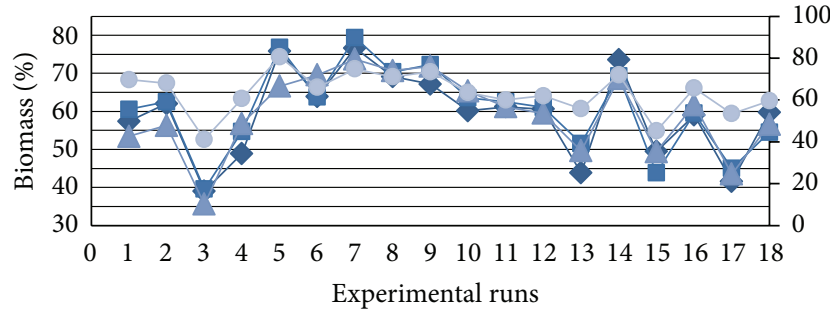

(a) Biomass residues after $\mathrm{Na}_{2} \mathrm{~S}$ treatment

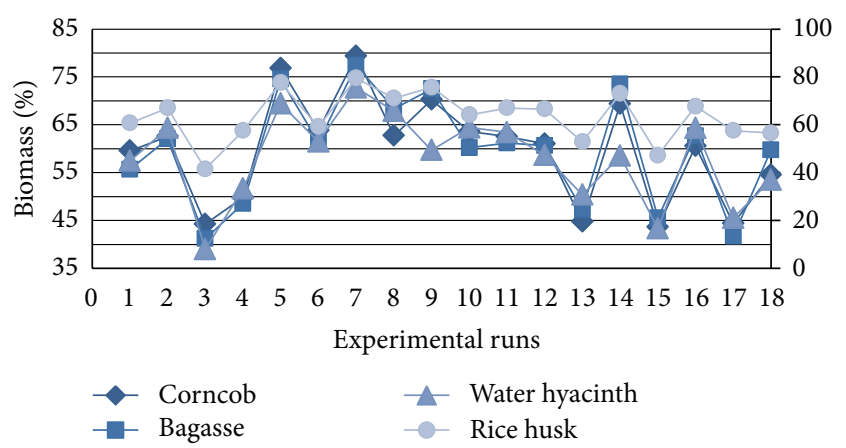

(b) Biomass residues after $\mathrm{Na}_{2} \mathrm{SO}_{3}$ treatment

FIGURE 2: Biomass residues during different experimental runs: (a) when biomass was treated with $\mathrm{Na}_{2} \mathrm{~S}$; (b) when biomass was treated with $\mathrm{Na}_{2} \mathrm{SO}_{3}$.

The biomass weight loss accounted for the removal of lignin and extractives or hydrolysis of the hemicellulose. The order of decreasing the biomass weight during pretreatment step was $\mathrm{WH}>\mathrm{BG}>\mathrm{CC}>\mathrm{RH}$. More weight loss observed with $\mathrm{Na}_{2} \mathrm{~S}$ as compared with $\mathrm{Na}_{2} \mathrm{SO}_{3}$. WH shows $26.32 \%-$ $65.73 \%$ weight loss, while corncob and bagasse show $20.21 \%$ $60.38 \%$. Less lignin content of water hyacinth and more hemicellulose hydrolysis, results in more weight loss during pretreatment. Minute quantity of sucrose was present in the pretreated hydrolyzates of BG and RH (Figure 3(a)). Amount of hemicellulose present in pretreated corncob was $15.61 \%$ followed by that of bagasse which was $10.46 \%$ (dry wt.), while $\mathrm{WH}$ and RH show only up to $2 \%$ hemicellulose after pretreatment. Water hyacinth and rice husk shows more hydrolysis of hemicellulose ( $>95 \%$ ) as compared to corncob and bagasse (>75\%). Ndazi et al. 2007, revealed that $4.0 \%-$ $8.0 \% \mathrm{NaOH}$, removed $96.0 \%$ lignin and $74.0 \%$ hemicellulose during pretreatment of the $\mathrm{RH}$, which increases the amount of cellulose $(\sim 80 \%)$ in the remaining biomass residue [45]. More hydrolysis of the hemicellulose in pretreated water hyacinth and rice husk was also confirmed by minute quantity of xylose in the enzymatic hydrolyzates (Figure 3(b)). Reduction in lignin content reached up to $97.54 \%$ in pretreatment step which was greater than $\mathrm{NaOH}(1.0 \%)$ treatment $(85.0 \%)$ $[16,26]$. In $\mathrm{BG}$ and $\mathrm{WH}$, lignin was almost completely removed when pretreated with $\mathrm{Na}_{2} \mathrm{~S} . \mathrm{Na}_{2} \mathrm{~S}$ has dominant effect on the removal of the lignin as compared with $\mathrm{Na}_{2} \mathrm{SO}_{3}$. After removal of lignin and hemicellulose at optimized conditions, amount of cellulose increased in the residual biomass in different proportions (Figure 4 ). $\mathrm{Na}_{2} \mathrm{~S}$-treated water hyacinth biomass shows $86.63 \%$ cellulose followed by $84.51 \%$ from $\mathrm{Na}_{2} \mathrm{SO}_{3}$ treatment and rice husk which provides $83.79 \%$ from both treatments. BG shows $79.45 \%$ and $82.56 \%$ cellulose after $\mathrm{Na}_{2} \mathrm{SO}_{3}$ and $\mathrm{Na}_{2} \mathrm{~S}$ treatment, respectively, while corncob shows $70.85 \%$ cellulose. In all treated biomass substrates, 


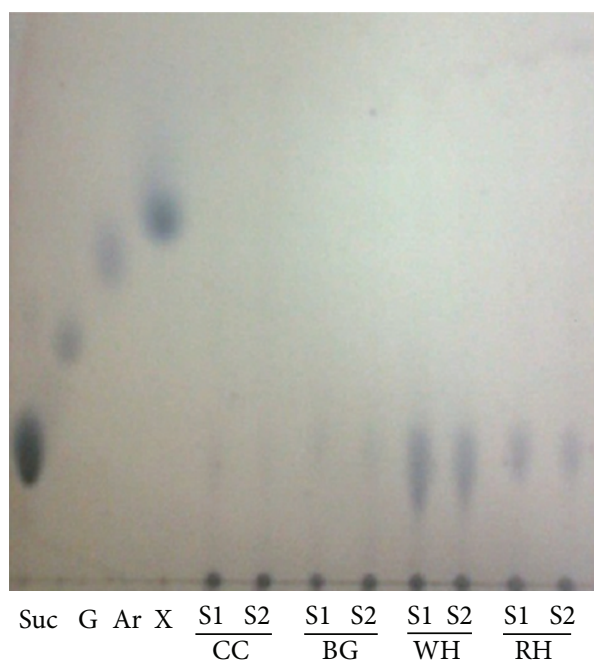

(a)

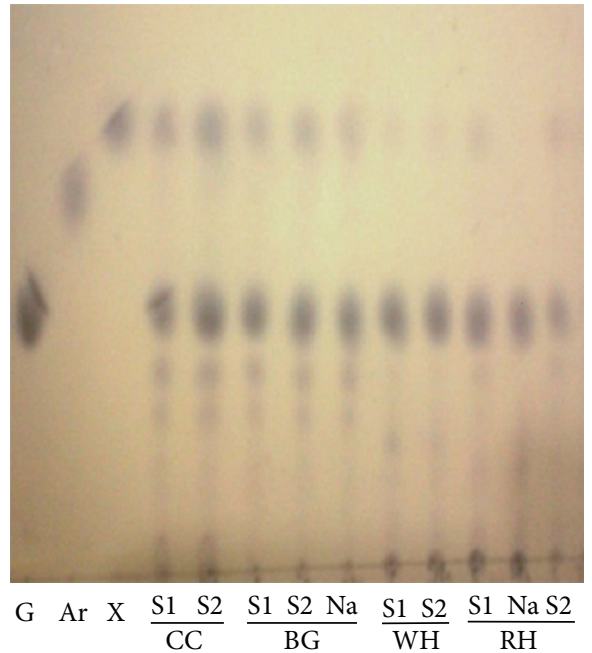

(b)

FIgURE 3: TLC images showing monomeric sugars in hydrolyzates (a) pretreated at $130^{\circ} \mathrm{C}$ for $3 \mathrm{~h}$; (b) after enzymatic hydrolysis (Suc: sucrose, G: glucose, Ar: arabinose, X: xylose, S1: sodium sulfide, S2: sodium sulfite, and $\mathrm{Na}: \mathrm{NaOH}$ ).

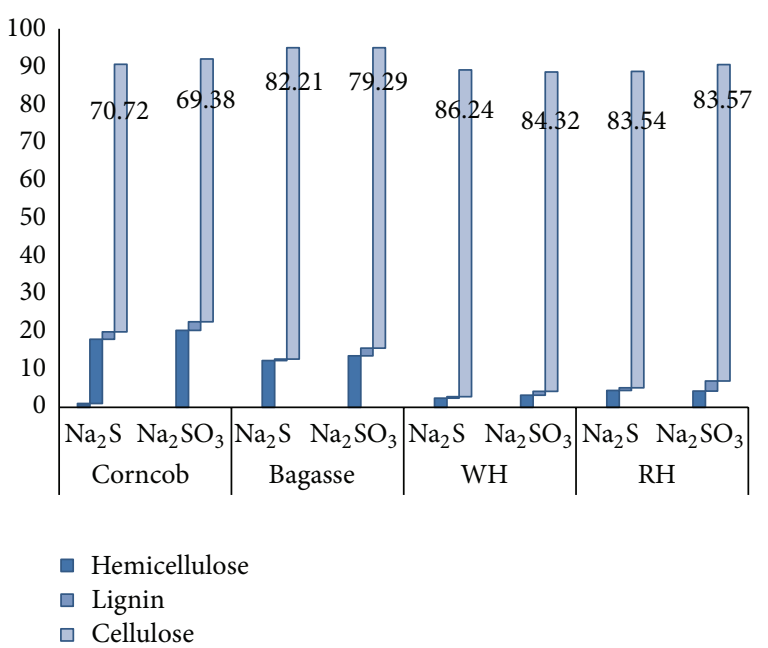

FIGURE 4: Composition of biomass after optimized pretreatment conditions.

nearly $85.0 \%-95.0 \%$ polysaccharide material was present for enzymatic hydrolysis.

3.2. Effects of Independent Variables on Hydrolysis Yield. The enzymatic hydrolysis yield of corncob biomass was greatly influenced by the temperature and time of pretreatment. Hydrolysis yields obtained after different pretreatments with $\mathrm{Na}_{2} \mathrm{~S}$ and $\mathrm{Na}_{2} \mathrm{SO}_{3}$ were shown in Figure 5. CC pretreated with $1.0 \% \mathrm{Na}_{2} \mathrm{~S}$ produces $55.0 \%$ and $86.0 \%$ hydrolysis yields at $90^{\circ} \mathrm{C}$ and $130^{\circ} \mathrm{C}$, respectively. There is apparent difference between the hydrolysis yields when the concentration of the catalyst during pretreatment was changed from $1.0 \%$ to $3.0 \%$ at low temperature, $56.62 \%$ and $67.92 \%$ yields were obtained when $\mathrm{Na}_{2} \mathrm{~S}$ (Figure 5(a)) was used during pretreatment at $90^{\circ} \mathrm{C}$, respectively. When $3.0 \% \mathrm{Na}_{2} \mathrm{~S}$ was used at $130^{\circ} \mathrm{C}$, the time of pretreatment has no prominent effect on hydrolysis yield, while at $1.0 \%$ concentration, the effect of time was dominant, produces $82.71 \%$ and $87.69 \%$ hydrolysis yield at $130^{\circ} \mathrm{C}$ with $1.0 \%$ and $3.0 \% \mathrm{Na}_{2} \mathrm{~S}$ catalysts correspondingly. The hydrolysis of bagasse was affected with the temperature of pretreatment and duration of time along with the catalyst concentration as well. At high temperature and low concentration $(1.0 \%)$ of $\mathrm{Na}_{2} \mathrm{~S}$, hydrolysis yield obtained were $80.57 \%$ and $87.41 \%$ when duration of time was $1.0 \mathrm{~h}$ and $3.0 \mathrm{~h}$, respectively, while at low temperature $53.28 \%$ and $63.46 \%$ hydrolysis yield was achieved. At high concentrations of $\mathrm{Na}_{2} \mathrm{~S}$ there was no much difference in the hydrolysis yield due to duration of time for pretreatment. In case of $\mathrm{Na}_{2} \mathrm{SO}_{3}$ pretreatment, only at lower catalyst concentration, time was affected on the hydrolysis yield at lower temperature but at high temperature difference was not prominent in hydrolysis. At maximum and minimum concentration of catalyst, temperature has a major effect on the hydrolysis yield providing $61.41 \%-68.36 \%$ and $82.51 \%$ yield at $90^{\circ} \mathrm{C}$ and $130^{\circ} \mathrm{C}$, respectively. Enzymatic hydrolysis of WH biomass was favored at high temperature and longer time of pretreatment when catalyst $\left(\mathrm{Na}_{2} \mathrm{~S}\right)$ concentration was low $(1.0 \%)$, while at high concentration, short time $(1.0 \mathrm{~h})$ of pretreatment yielded higher hydrolysis rate $(84.81 \%)$. At low temperature, $56.35 \%$ and $68.71 \%$ hydrolysis yield was obtained from $1.0 \%$ and $3.0 \%$ catalyst concentration, respectively, while at $130^{\circ} \mathrm{C}, 85.0 \%$ enzymatic hydrolysis yield was obtained from sodium sulfide $(1.0 \%)$. Only the effect of temperature was prominent on hydrolysis yield when $3.0 \%$ of $\mathrm{Na}_{2} \mathrm{SO}_{3}$ was used during pretreatment step, providing $71.62 \%$ and $84.64 \%$ hydrolysis yields at $90^{\circ} \mathrm{C}$ and $130^{\circ} \mathrm{C}$, respectively. With $1.0 \%$ concentration of $\mathrm{Na}_{2} \mathrm{SO}_{3}$ (Figure 5(b)), the effect of both temperature and time was prominent (79.32 and $86.54 \%$ yields). The hydrolysis of the $\mathrm{RH}$ was affected with the temperature of pretreatment and duration of time along with the catalyst concentration. High 


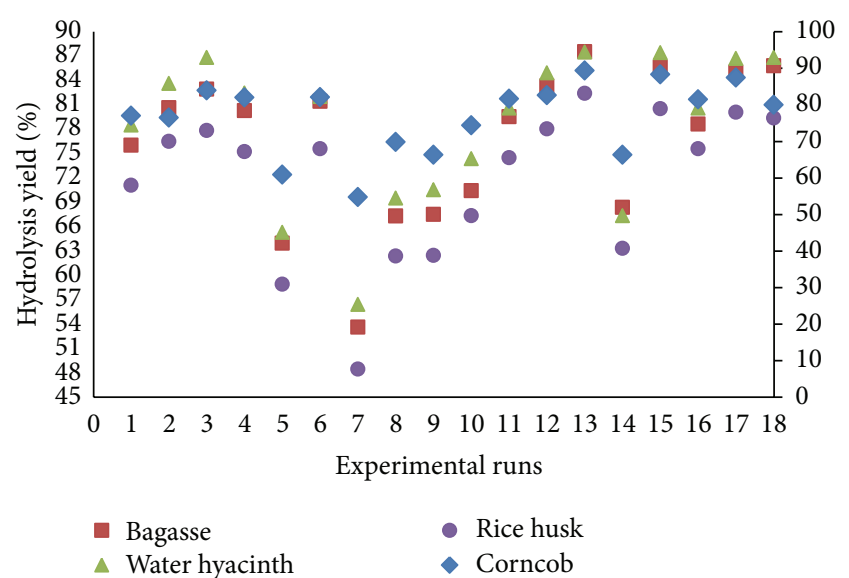

(a) Enzymatic hydrolysis yield (\%) from $\mathrm{Na}_{2} \mathrm{~S}$ treated substrates
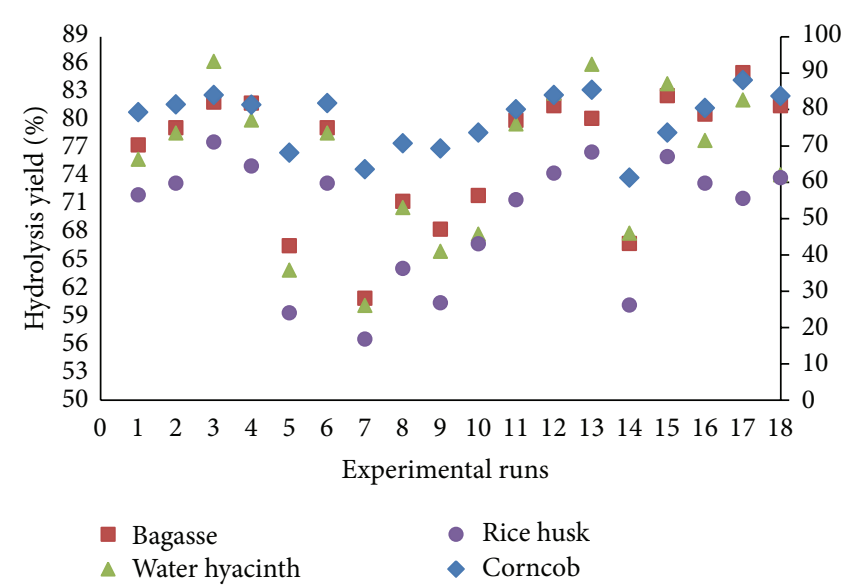

(b) Enzymatic hydrolysis yield (\%) from $\mathrm{Na}_{2} \mathrm{SO}_{3}$ treated substrates

FIGURE 5: Hydrolysis yield during different experimental runs: (a) when biomass was treated with $\mathrm{Na}_{2} \mathrm{~S}$; (b) when biomass was treated with $\mathrm{Na}_{2} \mathrm{SO}_{3}$.

temperature $\left(130^{\circ} \mathrm{C}\right)$ and $1.0 \%$ concentration of $\mathrm{Na}_{2} \mathrm{~S}$ provided $76.43 \%$ and $81.53 \%$ hydrolysis yields when pretreatment time was $1.0 \mathrm{~h}$ and $3.0 \mathrm{~h}$, respectively, while at $90^{\circ} \mathrm{C}, 58.37 \%$ yield was achieved. At high concentration of $\mathrm{Na}_{2} \mathrm{~S}$ there was no difference in the yield due to time of pretreatment; only temperature improves the hydrolysis yield. In case of $\mathrm{Na}_{2} \mathrm{SO}_{3}$ pretreatment, catalyst concentration along with temperature has a major effect on the hydrolysis yield providing $56.82 \%-$ $64.57 \%$ and $78.17 \%$ yield at $90^{\circ} \mathrm{C}$ and $130^{\circ} \mathrm{C}$, respectively.

3.3. Response Surface for the Interaction of Catalyst Conc., Temperature, and Time on Hydrolysis Yield. The fitness of the model was verified through different diagnostic checks. Residuals were found to follow the normality, and the plots of predicted versus actual yields (Figures 6(a) and 6(b)) also ascertained the overall fitness of the suggested model. Analysis of variance (ANOVA) for the quadratic models described that these models were sufficient to express the actual relationship between the response and significant variables, with a satisfactory coefficient of determination $R^{2}$ \{WH: $R=0.96^{(\mathrm{a})}$ and $0.98^{(\mathrm{b})} ; \mathrm{RH}: R=0.96^{(\mathrm{a})}$ and $0.97^{(\mathrm{b})}$; BG: $R=0.96^{(\mathrm{a})}$ and $0.98^{(\mathrm{b})} ; \mathrm{CC}: R=0.98^{(\mathrm{a})}$ and $0.98^{(\mathrm{b})}$ for $\mathrm{Na}_{2} \mathrm{~S}^{(\mathrm{a})}$ and $\mathrm{Na}_{2} \mathrm{SO}_{3}{ }^{(\mathrm{b})}$, resp.\}. These values which were in reasonable agreement with the adjusted $R^{2}$ indicated $93.0 \%-$ $98.0 \%$ of the variability in the response ensuring a satisfactory adjustment of a quadratic model to the experimental data. Significance of linear terms, that is, catalyst concentration $(\%)$, time $(\mathrm{h})$, and temperature $(t)$ for pretreatment, was found to be important as their $P$ values (prob $>F$ ) obtained were $<0.05$. Also, the $P$-value of the lack of fit for CC: $0.2431^{(\mathrm{a})}, 0.0880^{(\mathrm{b})}$; BG: $0.4355^{(\mathrm{a})}, 0.2060^{(\mathrm{b})}$, WH: $0.2497^{(\mathrm{a})}$, $0.1991^{(\mathrm{b})}$; RH: $0.0832^{(\mathrm{a})}$ and $0.1357^{(\mathrm{b})}$, respectively, confirmed that the polynomial models fit the processing (Table 3 ).

3.4. Optimization of Pretreatment Factors for Maximum Hydrolysis Yield. In order to optimize the reaction conditions for the production of high enzymatic hydrolysis yield, RMS was used for experimental purpose. After performing the enzymatic hydrolysis of pretreated materials obtained from the reaction conditions predefined by the RSM and statistical analysis of the data obtained, numerical and graphical optimization was performed. A variety of pretreatment conditions, with desirability 1.0 were selected for maximum hydrolysis yield at lowest catalyst level (1.0\% catalyst). When CC was used as lignocellulosic substrate for production of fermentation sugars by using $\mathrm{Na}_{2} \mathrm{~S}^{(\mathrm{a})}$ as a catalyst, the optimum factors were obtained as follows: $1.0 \% \mathrm{Na}_{2} \mathrm{~S}^{(\mathrm{a})}$ at reaction temperature of $130^{\circ} \mathrm{C}$ for $2.34 \mathrm{~h}$ and with $\mathrm{Na}_{2} \mathrm{SO}_{3}{ }^{(b)}$ concentration, $1.0 \%$ at temperature $130^{\circ} \mathrm{C}$ for $2.30 \mathrm{~h}$. Similarly of maximum hydrolysis yield was achieved from pretreated bagasse, when it treated with $\mathrm{Na}_{2} \mathrm{~S}^{(\mathrm{a})}(1.0 \%)$ at temperature $130^{\circ} \mathrm{C}$ for $3.0 \mathrm{~h}$ and $\mathrm{Na}_{2} \mathrm{SO}_{3}{ }^{(\mathrm{b})}$ : concentration $1.0 \%$ at temperature $130^{\circ} \mathrm{C}$ for $2.0 \mathrm{~h}$. Correspondingly, maximum hydrolysis yield was achieved from pretreated $\mathrm{WH}$, when it treated with $\mathrm{Na}_{2} \mathrm{~S}^{(\mathrm{a})}(1 \%)$ at temperature $130^{\circ} \mathrm{C}$ for $3.0 \mathrm{~h}$ and $\mathrm{Na}_{2} \mathrm{SO}_{3}{ }^{(\mathrm{b})}$ : concentration $1.0 \%$ at temperature $130^{\circ} \mathrm{C}$ for $2.39 \mathrm{~h}$. When rice husk was used as biomass source for production of reducing sugars, the maximum yield was obtained using $1.0 \% \mathrm{Na}_{2} \mathrm{~S}^{(\mathrm{a})}$ at temperature of $128^{\circ} \mathrm{C}$ for $2.95 \mathrm{~h}$ and $1.0 \%$ concentration of $\mathrm{Na}_{2} \mathrm{SO}_{3}{ }^{\text {(b) }}$ at pretreatment temperature of $125^{\circ} \mathrm{C}$ for $2.78 \mathrm{~h}$. When we use catalyst concentration at maximum level (3.0\%), keeping the temperature and time in range, 88-93\% hydrolysis yields were obtained. Keeping in view the processing safety, cost effectiveness and inhibition of by products on enzyme action, we have used the catalyst at lowest level (1.0\%), which decreases the yield from $93.0 \%$ to $88.0 \%$. To validate optimum yield, experiments with specified conditions were performed. The optimized conditions for corncob, bagasse, water hyacinth, and rice husk were mentioned in Table 4. Resultant hydrolysis yields obtained from optimum conditions are CC: $88.42^{\text {(a) }}$ and $86.32 \%{ }^{(\mathrm{b})}$, BG: $87.91^{(\mathrm{a})}$ and $84.06 \%^{(\mathrm{b})}$, WH: $85.93^{(\mathrm{a})}$ and $86.34 \%^{(\mathrm{b})}$, RH: $79.40^{\text {(a) }}$ and $77.17 \%^{\text {(b) }}$ showed that models were predictive and useful for the optimization of the pretreatment conditions. Previously, Jele et al., 2010 [16] obtained 74.0\% 
Predicted versus actual yield with $\mathrm{Na}_{2} \mathrm{~S}$-treated biomass (\%)

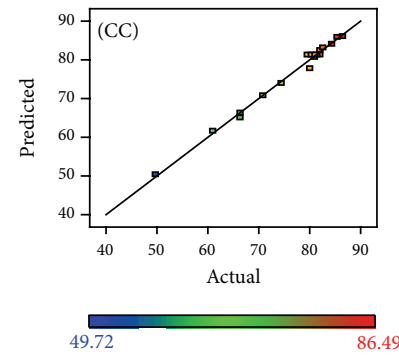

Color points by value of hydrolysis yield

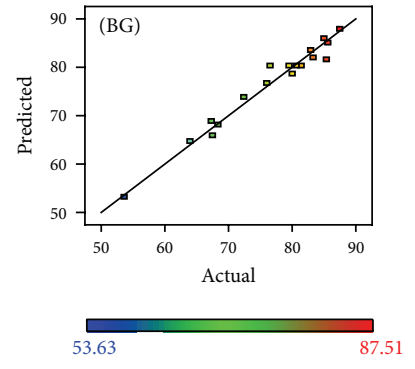

Color points by value of hydrolysis yield
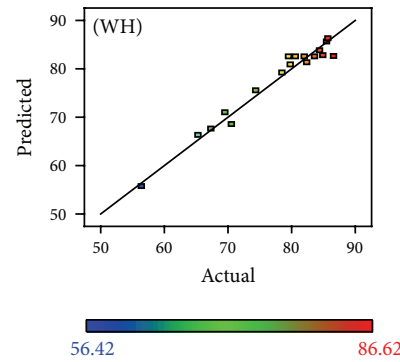

Color points by value of hydrolysis yield
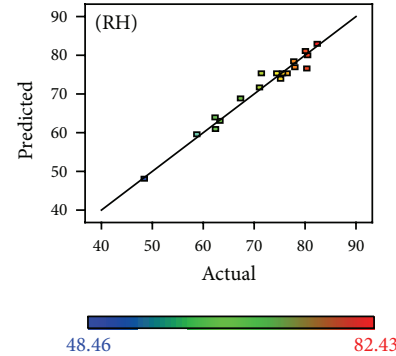

Color points by value of hydrolysis yield

Predicted versus actual yield with $\mathrm{Na}_{2} \mathrm{SO}_{3}$-treated biomass (\%)
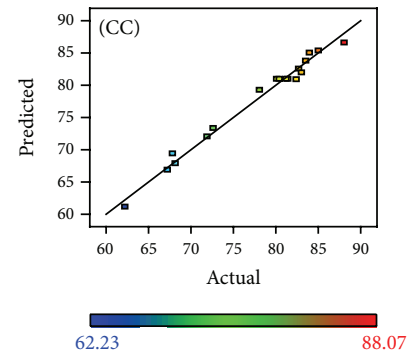

Color points by value of hydrolysis yield
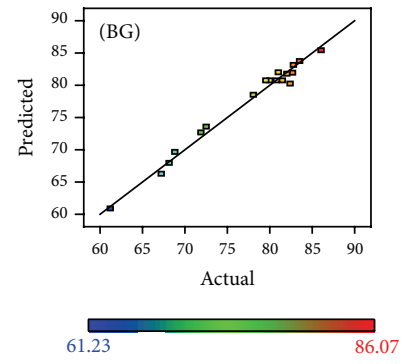

Color points by value of hydrolysis yield
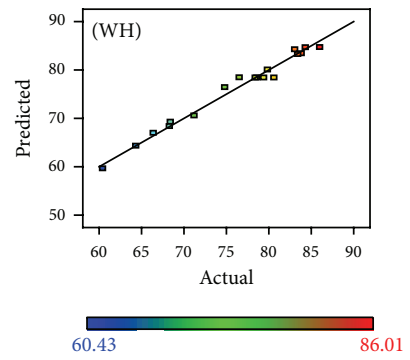

Color points by value of hydrolysis yield
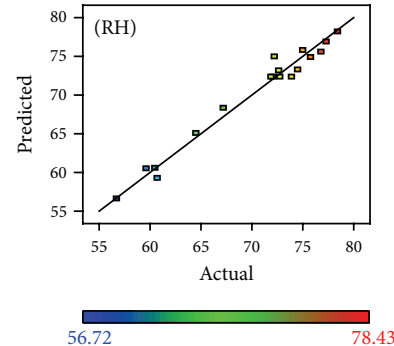

Color points by value of hydrolysis yield

(a)

Normal plot of residuals when biomass was treated with $\mathrm{Na}_{2} \mathrm{~S}$
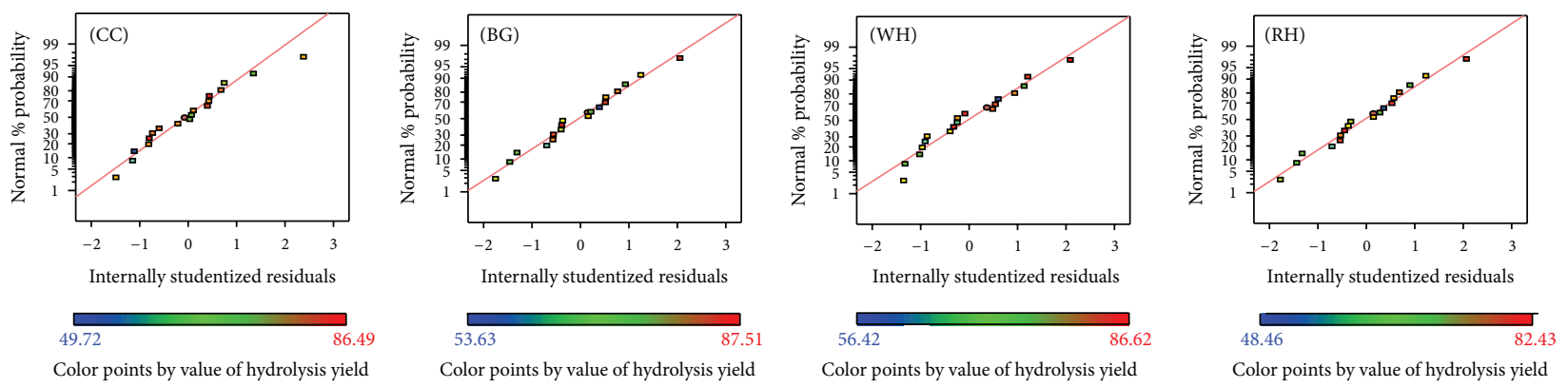

Normal plot of residuals when biomass was treated with $\mathrm{Na}_{2} \mathrm{SO}_{3}$
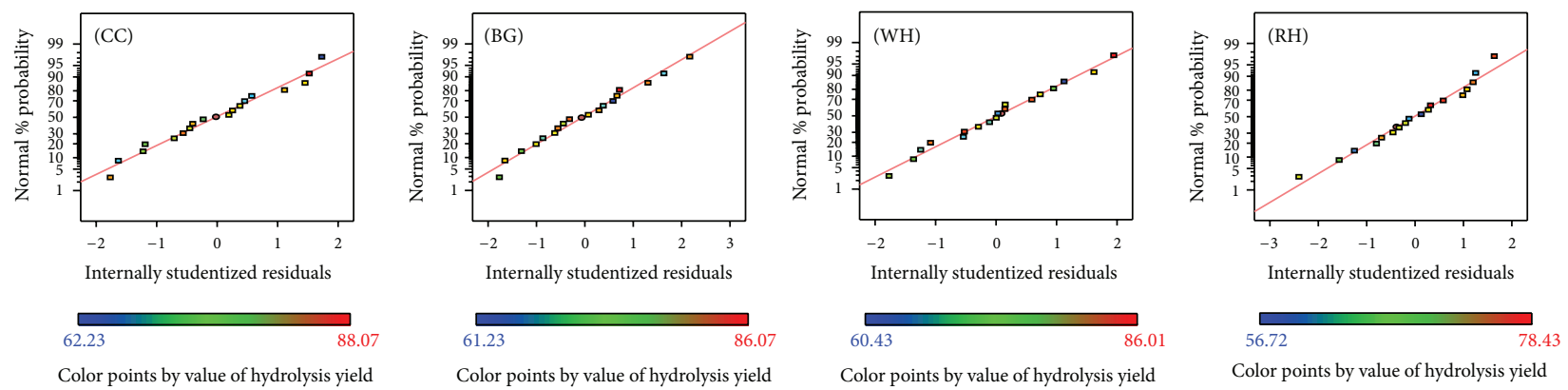

(b)

Figure 6: Predicted versus actual yield and normal plots of residuals obtained for different substrates.

hydrolysis yield from $\mathrm{NaOH}$-treated switchgrass, and $\mathrm{Zhu}$ et al., 2009 [20] obtained $90.0 \%$ cellulose conversion yield by using $(9.0 \%)$ sodium bisulfite along with sulphuric acid for pretreatment of wood chips at $180^{\circ} \mathrm{C}$, which has higher severity conditions. When pretreatment was done with $\mathrm{Na}_{2} \mathrm{~S}$, higher hydrolysis yield was obtained due to more lignin removal, depolymerization of the hemicellulose, and decrease in crystallinity of the cellulose as compared to $\mathrm{Na}_{2} \mathrm{SO}_{3}$ which removed slight less lignin during pretreatment. Rice husk yielded less amount of reducing sugars as compared with other biomass sources (Table 4). If we use these pretreatment conditions at bulk scale, the benefit of the process increases 
TABLE 3: Analysis of variance (ANOVA) of fitted model.

\begin{tabular}{|c|c|c|c|c|c|c|c|}
\hline & Model & Source & Sum of squares & $\mathrm{df}$ & Mean square & $F$ value & $\begin{array}{c}P \text { value } \\
\text { Prob }>F\end{array}$ \\
\hline \multirow{10}{*}{ Corncob } & \multirow{5}{*}{$\begin{array}{l}\mathrm{Na}_{2} \mathrm{~S}^{(\mathrm{a})} \\
\mathrm{NaOH}(0.5 \%)\end{array}$} & Model & 1461.27 & 9 & 162.36 & \multirow{2}{*}{72.6} & \multirow{2}{*}{$<0.0001$ significant } \\
\hline & & Residual & 17.95 & 8 & 2.24 & & \\
\hline & & Lack of fit & 14.45 & 5 & 2.89 & \multirow{2}{*}{2.48} & \multirow{2}{*}{0.2431 not significant } \\
\hline & & Pure error & 3.50 & 3 & 1.17 & & \\
\hline & & Cor total & 1479.22 & 17 & & & \\
\hline & \multirow{5}{*}{$\begin{array}{l}\mathrm{Na}_{2} \mathrm{SO}_{3}^{(\mathrm{b})} \\
\mathrm{NaOH}(0.5 \%)\end{array}$} & Model & 958.6 & 9 & 106.51 & \multirow{2}{*}{67.89} & \multirow{2}{*}{$<0.0001$ significant } \\
\hline & & Residual & 12.55 & 8 & 1.57 & & \\
\hline & & Lack of fit & 11.39 & 5 & 2.28 & \multirow{3}{*}{5.87} & \multirow{3}{*}{0.0880 not significant } \\
\hline & & Pure error & 1.16 & 3 & 0.39 & & \\
\hline & & Cor total & 971.15 & 17 & & & \\
\hline \multirow{10}{*}{ Bagasse } & \multirow{5}{*}{$\begin{array}{l}\mathrm{Na}_{2} \mathrm{~S}^{(\mathrm{a})} \\
\mathrm{NaOH}(0.5 \%)\end{array}$} & Model & 1392.09 & 9 & 154.68 & \multirow{2}{*}{27.98} & \multirow{2}{*}{$<0.0001$ significant } \\
\hline & & Residual & 44.22 & 8 & 5.53 & & \\
\hline & & Lack of fit & 30.42 & 5 & 6.08 & \multirow{2}{*}{1.32} & \multirow{2}{*}{0.4355 not significant } \\
\hline & & Pure error & 13.80 & 3 & 4.60 & & \\
\hline & & Cor total & 1436.32 & 17 & & & \\
\hline & \multirow{5}{*}{$\begin{array}{l}\mathrm{Na}_{2} \mathrm{SO}_{3}^{(\mathrm{b})} \\
\mathrm{NaOH}(0.5 \%)\end{array}$} & Model & 834.55 & 9 & 92.73 & \multirow{2}{*}{56.90} & \multirow{2}{*}{$<0.0001$ significant } \\
\hline & & Residual & 13.04 & 8 & 1.63 & & \\
\hline & & Lack of fit & 10.79 & 5 & 2.16 & \multirow{3}{*}{2.89} & \multirow{3}{*}{0.2060 not significant } \\
\hline & & Pure error & 2.24 & 3 & 0.75 & & \\
\hline & & Cor total & 847.59 & 17 & & & \\
\hline \multirow{10}{*}{ Water hyacinth } & \multirow{5}{*}{$\begin{array}{l}\mathrm{Na}_{2} \mathrm{~S}^{(\mathrm{a})} \\
\mathrm{NaOH}(0.5 \%)\end{array}$} & Model & 1189.95 & 9 & 132.22 & \multirow{2}{*}{22.37} & $<0.0001$ significant \\
\hline & & Residual & 47.29 & 8 & 5.91 & & \\
\hline & & Lack of fit & 37.89 & 5 & 7.58 & 2.42 & 0.2491 not significant \\
\hline & & Pure error & 9.40 & 3 & 3.13 & 2.42 & 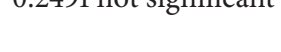 \\
\hline & & Cor total & 1237.25 & 17 & & & \\
\hline & & Model & 990.81 & 9 & 110.09 & 49.57 & $<0.0001$ significant \\
\hline & $\mathrm{Na}_{2} \mathrm{SO}_{2}^{(\mathrm{b})}$ & Residual & 17.77 & 8 & 2.22 & & \\
\hline & $\mathrm{NaOH}(0.5 \%)$ & Lack of fit & 14.78 & 5 & 2.96 & 2.97 & 0.1997 not significant \\
\hline & & Pure error & 2.99 & 3 & 1.0 & & \\
\hline & & Cor total & 1008.58 & 17 & & & \\
\hline & & Model & 1399.28 & 9 & 155.48 & 27.82 & $<0.0001$ significant \\
\hline & & Residual & 44.70 & 8 & 5.59 & 21.02 & - \\
\hline & $\begin{array}{l}\mathrm{Na}_{2} \mathrm{~S} \\
\mathrm{NaOH}(0.5 \%)\end{array}$ & Lack of fit & 30.15 & 5 & 6.03 & 1.24 & 0.0832 not significant \\
\hline & & Pure error & 14.55 & 3 & 4.85 & & \\
\hline Rice husk & & Cor total & 1443.98 & 17 & & & \\
\hline & & Model & 770.44 & 9 & 85.86 & 34.61 & $<0.0001$ significant \\
\hline & & Residual & 19.79 & 8 & 2.47 & & \\
\hline & $\begin{array}{l}\mathrm{Na}_{2} \mathrm{SU}_{3} \\
\mathrm{NaOH}(0.5 \%)\end{array}$ & Lack of fit & 17.29 & 5 & 3.36 & 4.15 & 0.1357 not significant \\
\hline & & Pure error & 2.50 & 3 & 0.83 & & \\
\hline & & Cor total & 790.23 & 17 & & & \\
\hline
\end{tabular}

as the electricity charges during pretreatment decreases ( $\mathrm{Zhu}$ et al., 2009) [20] due to lignin and other byproducts which could be used for energy production as described in the flow diagram (Figure 1).
3.5. Lactic Acid Production from Enzymatic Hydrolyzate. The enzymatic hydrolyzate obtained from the most effective pretreatment condition, containing glucose and xylose was used as a fermenting medium for lactic acid production. 
TABLE 4: Optimized hydrolysis yield with independent variables used during pretreatment.

\begin{tabular}{|c|c|c|c|c|c|c|}
\hline Substrate & Catalyst & $\begin{array}{c}\text { Catalyst } \\
(\%)\end{array}$ & $\begin{array}{l}\text { Time } \\
\text { (h) }\end{array}$ & $\begin{array}{c}\text { Temperature } \\
\left({ }^{\circ} \mathrm{C}\right) \\
\end{array}$ & $\begin{array}{c}\text { Hydrolysis yield (\%) } \\
\text { (pretreatment) }\end{array}$ & $\begin{array}{c}\text { Hydrolysis yield (\%) } \\
\text { (enzymatic) }\end{array}$ \\
\hline \multirow{2}{*}{ Corncob } & $\mathrm{Na}_{2} \mathrm{~S}$ & 1.0 & 2.34 & 130.0 & n.d. & 88.43 \\
\hline & $\mathrm{Na}_{2} \mathrm{SO}_{3}$ & 1.0 & 2.30 & 130.0 & n.d. & 86.32 \\
\hline \multirow{2}{*}{ Bagasse } & $\mathrm{Na}_{2} \mathrm{~S}$ & 1.0 & 3.00 & 130.0 & n.d. & 87.91 \\
\hline & $\mathrm{Na}_{2} \mathrm{SO}_{3}$ & 1.0 & 2.00 & 130.0 & n.d. & 84.06 \\
\hline \multirow{2}{*}{ Water hyacinth } & $\mathrm{Na}_{2} \mathrm{~S}$ & 1.0 & 3.00 & 130.0 & n.d. & 85.93 \\
\hline & $\mathrm{Na}_{2} \mathrm{SO}_{3}$ & 1.0 & 2.39 & 130.0 & n.d. & 86.34 \\
\hline \multirow{2}{*}{ Rice husk } & $\mathrm{Na}_{2} \mathrm{~S}$ & 1.0 & 2.95 & 128.0 & n.d. & 79.40 \\
\hline & $\mathrm{Na}_{2} \mathrm{SO}_{3}$ & 1.0 & 2.78 & 125.8 & n.d. & 77.17 \\
\hline
\end{tabular}

n.d.: not determined due to dark-color liquor and absence of monomer sugars in TLC images.

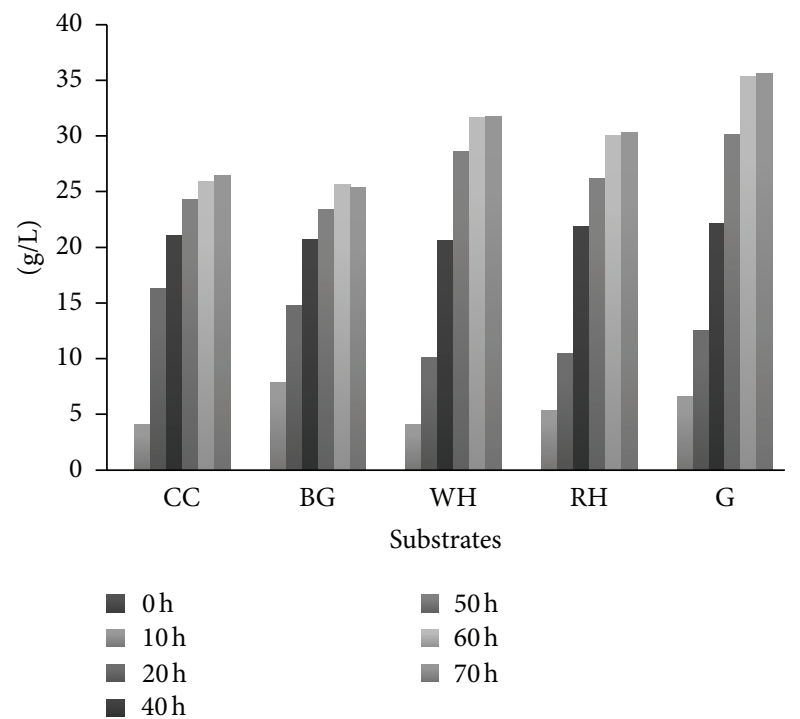

(a) Lactic acid production from different substrates

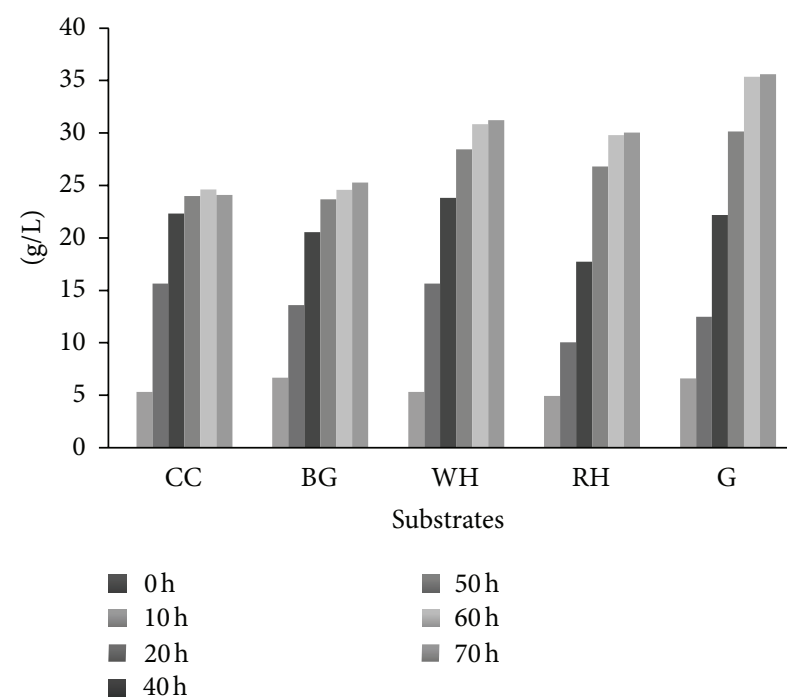

(b) Lactic acid production from different substrates

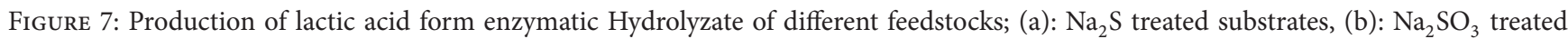
substrates.

The reducing sugars concentration was adjusted at $40.0 \mathrm{gL}^{-1}$ by diluting and concentrating the hydrolyzate. Pure glucose yielded $35.6 \mathrm{gL}^{-1}$ of lactic acid showing $96.0 \%$ conversion yield. The enzymatic hydrolyzates of sulfite- and sulfidetreated corncob and bagasse yielded 26.47 and $25.36 \mathrm{gL}^{-1}$ of lactic acid, respectively, while water hyacinth and rice husk yielded 31.71 and $30.31 \mathrm{gL}^{-1}$ of lactic acid (Figure 7). Ali et al., 2009 [46], obtained $25.62 \mathrm{gL}^{-1}$ lactic acid from corncob hydrolyzate through $L$. delbrueckii, while Shen and Xia 2006 [47] obtained $34.40 \mathrm{gL}^{-1}$ of lactic acid in $54.0 \mathrm{~h}$ from corncob residue having concentration of $60.0 \mathrm{gL}^{-1}$ with productivity of $0.669 \mathrm{gL}^{-1} \cdot \mathrm{h}^{-1}$. This difference in the conversion yield was due to the presence of xylose present in the enzymatic hydrolyzate of corncob and bagasse which was not fermented by L. acidophilus. These results showed that cellulosic hydrolyzate could be used effectively for the production of lactic acid. Productivity of lactic acid from pure glucose was $0.59 \mathrm{gL}^{-1} \cdot \mathrm{h}^{-1}$, while enzymatic hydrolyzate of water hyacinth and rice husk showed 0.52 and $0.50 \mathrm{gL}^{-1} \cdot \mathrm{h}^{-1}$ which were greater than corncob $\left(0.44 \mathrm{gL}^{-1} \cdot \mathrm{h}^{-1}\right)$ and bagasse $\left(0.42 \mathrm{gL}^{-1} \cdot \mathrm{h}^{-1}\right)$ hydrolyzate due to the absence of xylose (Table 5). Wee et al., 2006 [31], reported lactic acid productivity $2.2-1.3 \mathrm{gL}^{-1} \cdot \mathrm{h}^{-1}$ by using the Lactobacillus sp. RKY2 on glucose. DNS analysis showed that enzymatic hydrolyzate of water hyacinth and rice husk after lactic acid fermentation showed $2.0-3.0 \mathrm{gL}^{-1}$ of reducing sugars while corncob and bagasse showed 7.64-9.67 $\mathrm{gL}^{-1}$ of sugars (xylose) which were the cause of less productivity of lactic acid as compared with the productivity of pure glucose.

\section{Conclusions}

Corncob, bagasse, water hyacinth, and rice husk have less lignin content and more cellulosic content. These could be potential sources for fermentable sugars which can be achieved through pretreatment and enzymatic hydrolysis. Pretreatment was done with $\mathrm{Na}_{2} \mathrm{~S}$ or $\mathrm{Na}_{2} \mathrm{SO}_{3}$ in the presence of $\mathrm{NaOH}$ for the removal of lignin and the decreasing of 
TABLE 5: Kinetic parameters of lactic acid fermentations during batch culturing of Lactobacillus acidophilus.

\begin{tabular}{|c|c|c|c|c|c|}
\hline Substrate & Reagent for pretreatment & $\begin{array}{c}\gamma(\text { initial sugar conc.) } \\
\mathrm{gL}^{-1}\end{array}$ & $\begin{array}{c}\gamma(\text { lactic acid }) \\
\mathrm{gL}^{-1}\end{array}$ & $\begin{array}{c}\eta \text { (lactic acid) } \\
\mathrm{gg}^{-1}\end{array}$ & $\begin{array}{c}\text { Productivity } \\
\mathrm{gL}^{-1} \cdot \mathrm{h}^{-1} \\
\end{array}$ \\
\hline \multirow{2}{*}{ Corncob } & $\mathrm{Na}_{2} \mathrm{~S}$ & 40.0 & $26.48 \pm 0.32$ & 0.76 & 0.44 \\
\hline & $\mathrm{Na}_{2} \mathrm{SO}_{3}$ & 40.0 & $24.11 \pm 0.94$ & 0.75 & 0.40 \\
\hline \multirow{2}{*}{ Bagasse } & $\mathrm{Na}_{2} \mathrm{~S}$ & 40.0 & $25.27 \pm 0.46$ & 0.76 & 0.42 \\
\hline & $\mathrm{Na}_{2} \mathrm{SO}_{3}$ & 40.0 & $25.36 \pm 0.52$ & 0.76 & 0.42 \\
\hline \multirow{2}{*}{ Water hyacinth } & $\mathrm{Na}_{2} \mathrm{~S}$ & 40.0 & $31.73 \pm 0.82$ & 0.86 & 0.52 \\
\hline & $\mathrm{Na}_{2} \mathrm{SO}_{3}$ & 40.0 & $31.21 \pm 0.61$ & 0.86 & 0.52 \\
\hline \multirow{2}{*}{ Rice husk } & $\mathrm{Na}_{2} \mathrm{~S}$ & 40.0 & $30.31 \pm 0.69$ & 0.83 & 0.50 \\
\hline & $\mathrm{Na}_{2} \mathrm{SO}_{3}$ & 40.0 & $30.03 \pm 0.47$ & 0.83 & 0.50 \\
\hline Glucose & No treatment & 40.0 & $35.61 \pm 0.86$ & 0.96 & 0.59 \\
\hline
\end{tabular}

$\eta($ lactic acid $)=$ lactic acid produced/sugar consumed $(\mathrm{g} / \mathrm{g})$.

the crystallinity of the substrate for maximum enzyme action. The response surface methodology was employed successfully for the optimization of the pretreatment factors such as catalyst concentration, temperature and time. Keeping in mind the minimum catalyst concentration, optimized level of different factors were: $\mathrm{Na}_{2} \mathrm{~S}$ concentration $1.0 \%$, temperature $130^{\circ} \mathrm{C}$, time $2.30-3.00 \mathrm{~h}$ and $\mathrm{Na}_{2} \mathrm{SO}_{3}$ concentration $1.0 \%$, temperature $130^{\circ} \mathrm{C}$ and time $2.00-2.78 \mathrm{~h}$. At these conditions, the removal of lignin reached up to $97 \%$. The saccharification efficiency of $\mathrm{Na}_{2} \mathrm{~S}$-treated corncob, bagasse, water hyacinth and rice husk was found to be $88.48,87.91,85.93$ and $79.40 \%$ and the following $\mathrm{Na}_{2} \mathrm{SO}_{3} ; 86.32 \%, 84.06 \%$, $86.34 \%$, and $77.17 \%$, respectively. Pretreatment with $\mathrm{Na}_{2} \mathrm{~S}$ in the presence of $\mathrm{NaOH}$ showed higher sugar yield as compared with $\mathrm{Na}_{2} \mathrm{SO}_{3}$ except in $\mathrm{WH}$ case. The resulting sugars produced $26.47,25.36,31.71$, and $30.31 \mathrm{gL}^{-1}$ of lactic acid from corncob, bagasse, water hyacinth and rice husk, respectively, with productivity $0.42-0.52 \mathrm{gL}^{-1} \cdot \mathrm{h}^{-1}$. This study shows that combined $\mathrm{NaOH}$ and $\mathrm{Na}_{2} \mathrm{~S} / \mathrm{Na}_{2} \mathrm{SO}_{3}$ pretreatment has outstanding delignification capacity for saccharification of the cellulosic material at minimum concentration, and these biomass sources were considered a potential feedstocks for lactic acid production.

\section{Acknowledgments}

The authors gratefully acknowledge the financial support from the Higher Education Commission, Islamabad, Pakistan, and Genencor International, Inc., for providing enzyme samples.

\section{References}

[1] M. Neureiter, H. Danner, L. Madzingaidzo et al., "Lignocellulose feedstocks for the production of lactic acid," Chemical and Biochemical Engineering Quarterly, vol. 18, no. 1, pp. 55-63, 2004.

[2] L. R. Lynd, C. E. Wyman, and T. U. Gerngross, "Biocommodity engineering," Biotechnology Progress, vol. 15, no. 5, pp. 777-793, 1999.

[3] B. Hahn-Hägerdal, M. Galbe, M. F. Gorwa-Grauslund, G. Lidén, and G. Zacchi, "Bio-ethanol-the fuel of tomorrow from the residues of today," Trends in Biotechnology, vol. 24, no. 12, pp. 549-556, 2006.

[4] H. Palonen, Role of lignin in the enzymatic hydrolysis of lignocellulose [Ph.D. thesis of Technology], University of Technology, Espoo, Finland, 2004.

[5] H. B. Seo, S. Kim, H. Y. Lee, and K. H. Jung, "Improved bioethanol production using activated carbon-treated acid hydrolysate from Corn Hull in Pachysolen tannophilus," The Korean Society of Mycology, Mycobiology, vol. 37, no. 2, pp. 133140, 2009.

[6] P. Torre, B. Aliakbarian, B. Rivas, J. M. Domínguez, and A. Converti, "Release of ferulic acid from corn cobs by alkaline hydrolysis," Biochemical Engineering Journal, vol. 40, no. 3, pp. 500-506, 2008.

[7] B. Rivas, J. M. Domínguez, H. Domínguez, and J. C. Parajó, "Bioconversion of posthydrolysed autohydrolysis liquors: an alternative for xylitol production from corn cobs," Enzyme and Microbial Technology, vol. 31, no. 4, pp. 431-438, 2002.

[8] T. Khaliq, T. Mahmood, and A. Masood, "Effectiveness of farmyard manure, poultry manure and nitrogen for corn (Zea mays) productivity," International Journal of Agricultural Biology, vol. 2, no. 6, pp. 260-2263, 2004.

[9] FAOSTAT, Food and Agricultural Commodities Production, Food and Agriculture Organization of the United Nations, Rome, Italy, 2010.

[10] A. B. Hashim, H. Aminuddin, and K. B. Siva, "Nutrient content in rice husk ash of some Malaysian rice varieties," Pertanika Journal Tropical Agricultural Science, vol. 19, no. 1, pp. 77-80, 1996.

[11] H. Danner, Milchsatz-Fermentative-Herstellung, Aufarbeitung und Einsatz als Chemierohstoff [Ph.D. thesis], BOKUUniversity of Natural Resources and Applied Life Sciences, Vienna, Austria, 1998.

[12] K. K. Cheng, B. Y. Cai, J. A. Zhang et al., "Sugarcane bagasse hemicellulose hydrolysate for ethanol production by acid recovery process," Biochemical Engineering Journal, vol. 38, no. 1, pp. 105-109, 2008.

[13] P. Laopaiboon, A. Thani, V. Leelavatcharamas, and L. Laopaiboon, "Acid hydrolysis of sugarcane bagasse for lactic acid production," Bioresource Technology, vol. 101, no. 3, pp. 10361043, 2010.

[14] B. C. Saha, “ $\alpha$-L-arabinofuranosidases: biochemistry, molecular biology and application in biotechnology," Biotechnology Advances, vol. 18, no. 5, pp. 403-423, 2000. 
[15] A. Wingren, M. Galbe, C. Roslander, A. Rudolf, and G. Zacchi, "Effect of reduction in yeast and enzyme concentrations in a simultaneous-saccharification-and-fermentationbased bioethanol process: technical and economic evaluation," Applied Biochemistry and Biotechnology A, vol. 122, no. 1-3, pp. 485-499, 2005.

[16] J. Xu, J. J. Cheng, R. R. Sharma-Shivappa, and J. C. Burns, "Sodium hydroxide pretreatment of switchgrass for ethanol production," Energy and Fuels, vol. 24, no. 3, pp. 2113-2119, 2010.

[17] P. Kumar, D. M. Barrett, M. J. Delwiche, and P. Stroeve, "Methods for pretreatment of lignocellulosic biomass for efficient hydrolysis and biofuel production," Industrial and Engineering Chemistry Research, vol. 48, no. 8, pp. 3713-3729, 2009.

[18] T. A. Hsu, M. R. Ladisch, and G. T. Tsao, "Alcohol from cellulose," Chemical Technology, vol. 10, no. 5, pp. 315-319, 1980.

[19] D. Mishima, M. Tateda, M. Ike, and M. Fujita, "Comparative study on chemical pretreatments to accelerate enzymatic hydrolysis of aquatic macrophyte biomass used in water purification processes," Bioresource Technology, vol. 97, no. 16, pp. 2166-2172, 2006.

[20] J. Y. Zhu, X. J. Pan, G. S. Wang, and R. Gleisner, "Sulfite pretreatment (SPORL) for robust enzymatic saccharification of spruce and red pine," Bioresource Technology, vol. 100, no. 8, pp. 2411-2418, 2009.

[21] H. Meier, "On the behavior of wood hemicelluloses under different pulping conditions, Part I Birch hemicellulose," Svensk Papper Stidning, vol. 65, pp. 299-305, 1962.

[22] H. Meier, "On the behavior of wood hemicelluloses under different pulping conditions, Part II Spruce hemicellulose," Svensk Papper Stidning, vol. 65, pp. 589-594, 1962.

[23] K. Pfister and E. Sjostrom, "The formation of monosaccharides and aldonic and uronic acids during sulphite cooking," Paperi Ja Puu, vol. 59, pp. 711-720, 1977.

[24] E. Heuser, "Trends in fundamental research in the cellulose and wood pulp field," TAPPI, vol. 33, pp. 118-124, 1950.

[25] X. Zhao, L. Zhang, and D. Liu, "Comparative study on chemical pretreatment methods for improving enzymatic digestibility of crofton weed stem," Bioresource Technology, vol. 99, no. 9, pp. 3729-3736, 2008.

[26] R. A. Silverstein, Y. Chen, R. R. Sharma-Shivappa, M. D. Boyette, and J. Osborne, "A comparison of chemical pretreatment methods for improving saccharification of cotton stalks," Bioresource Technology, vol. 98, no. 16, pp. 3000-3011, 2007.

[27] M. L. Soto, H. Dominguez, M. J. Nunez, and J. M. Lema, "Enzymatic saccharification of alkali-treated sunflower hulls," Bioresource Technology, vol. 49, no. 1, pp. 53-59, 1994.

[28] D. G. MacDonald, N. N. Bakhshi, J. F. Mathews, A. Roychowdhury, P. Bajpai, and M. Moo-Young, "Alkali treatment of corn stover to improve sugar production by enzymatic hydrolysis," Biotechnology and Bioengineering, vol. 25, no. 8, pp. 2067-2076, 1983.

[29] M. Idrees, A. Adnan, S. Sheikh, and F. A. Qureshi, "Optimization of dilute acid pretreatment of water hyacinth biomass for enzymatic hydrolysis and ethanol production," EXCLI Journal, vol. 12, pp. 30-40, 2013.

[30] K. Y. Lee, J. S. So, and T. R. Heo, “Thin layer chromatographic determination of organic acids for rapid identification of bifidobacteria at genus level," Journal of Microbiological Methods, vol. 45 , no. 1, pp. 1-6, 2001.

[31] J. Y. Wee, N. K. Jin, and H. W. Ryu, "Lactic acid production with Lactobacillus sp. RKY2," Food Technology and Biotechnology, vol. 44, no. 2, pp. 293-298, 2006.
[32] L. Lin, R. Yan, Y. Liu, and W. Jiang, "In-depth investigation of enzymatic hydrolysis of biomass wastes based on three major components: cellulose, hemicellulose and lignin," Bioresource Technology, vol. 101, no. 21, pp. 8217-8223, 2010.

[33] C. D. Blasi, G. Signorelli, C. D. Russo, and G. Rea, "Product distribution from pyrolysis of wood and agricultural residues," Industrial and Engineering Chemistry Research, vol. 38, no. 6, pp. 2216-2224, 1999.

[34] S. Li, S. Xu, S. Liu, C. Yang, and Q. Lu, "Fast pyrolysis of biomass in free-fall reactor for hydrogen-rich gas," Fuel Processing Technology, vol. 85, no. 8-10, pp. 1201-1211, 2004.

[35] T. K. Ghose, "Measurement of cellulase activities," Pure and Applied Chemistry, vol. 59, no. 2, pp. 257-267, 1987.

[36] W. Dedsuksophon, K. Faungnawakij, V. Champreda, and N. Laosiripojana, "Hydrolysis/dehydration/aldol-condensation/ hydrogenation of lignocellulosic biomass and biomass-derived carbohydrates in the presence of $\mathrm{Pd} / \mathrm{WO}_{3}-\mathrm{ZrO}_{2}$ in a single reactor," Bioresource Technology, vol. 102, no. 2, pp. 2040-2046, 2011.

[37] D. M. Bai, R. Ban, X. M. Zhao, and Z. D. Hu, "Determination of lactic acid in fermentation broth of Rhizopus oryzae by reversed-phase high performance liquid chromatography (RPHPLC)," Chinese Journal of Chromatography, vol. 18, no. 6, pp. 527-528, 2000.

[38] J. X. Sun, X. F. Sun, H. Zhao, and R. C. Sun, "Isolation and characterization of cellulose from sugarcane bagasse," Polymer Degradation and Stability, vol. 84, no. 2, pp. 331-339, 2004.

[39] J. Gressel, "Transgenics are imperative for biofuel crops," Plant Science, vol. 174, no. 3, pp. 246-263, 2008.

[40] D. Mishima, M. Kuniki, K. Sei, S. Soda, M. Ike, and M. Fujita, "Ethanol production from candidate energy crops: water hyacinth (Eichhornia crassipes) and water lettuce (Pistia stratiotes L.)," Bioresource Technology, vol. 99, no. 7, pp. 2495-2500, 2008.

[41] S. S. Magdum, S. M. More, and A. A. Nadaf, "Biochemical conversion of acid-pretreated water hyacinth (Eichhornia Crassipes) to alcohol using Pichia Stipitis NCIM3497," International Journal of Advanced Biotechnology and Research, vol. 3, no. 2, pp. 585-590, 2012.

[42] Y. Sun and J. Cheng, "Hydrolysis of lignocellulosic materials for ethanol production: a review," Bioresource Technology, vol. 83, no. 1, pp. 1-11, 2002.

[43] S. Satimanont, A. Luengnaruemitchai, and S. Wongkasemjit, "Effect of temperature and time on dilute acid pretreatment of corn cobs," International Journal Chemical Biological Engineering, vol. 6, pp. 333-337, 2012.

[44] I. B. Ugheoke and O. Mamat, "A critical assessment and new research directions of rice husk silica processing methods and properties," Maejo International Journal of Science Technology, vol. 6, no. 03, pp. 430-448, 2012.

[45] B. S. Ndazi, C. Nyahumwa, and J. Tesha, "Chemical and thermal stability of rice husks against alkali treatment," BioResources, vol. 3, no. 4, pp. 1267-1277, 2008.

[46] Z. Ali, F. M. Anjum, and T. Zahoor, "Production of lactic acid from corn cobs hydrolysate through fermentation by Lactobaccillus delbrukii," African Journal of Biotechnology, vol. 8, no. 17, pp. 4175-4178, 2009.

[47] X. Shen and L. Xia, "Lactic acid production from cellulosic material by synergetic hydrolysis and fermentation," Applied Biochemistry and Biotechnology, vol. 133, no. 3, pp. 251-262, 2006. 

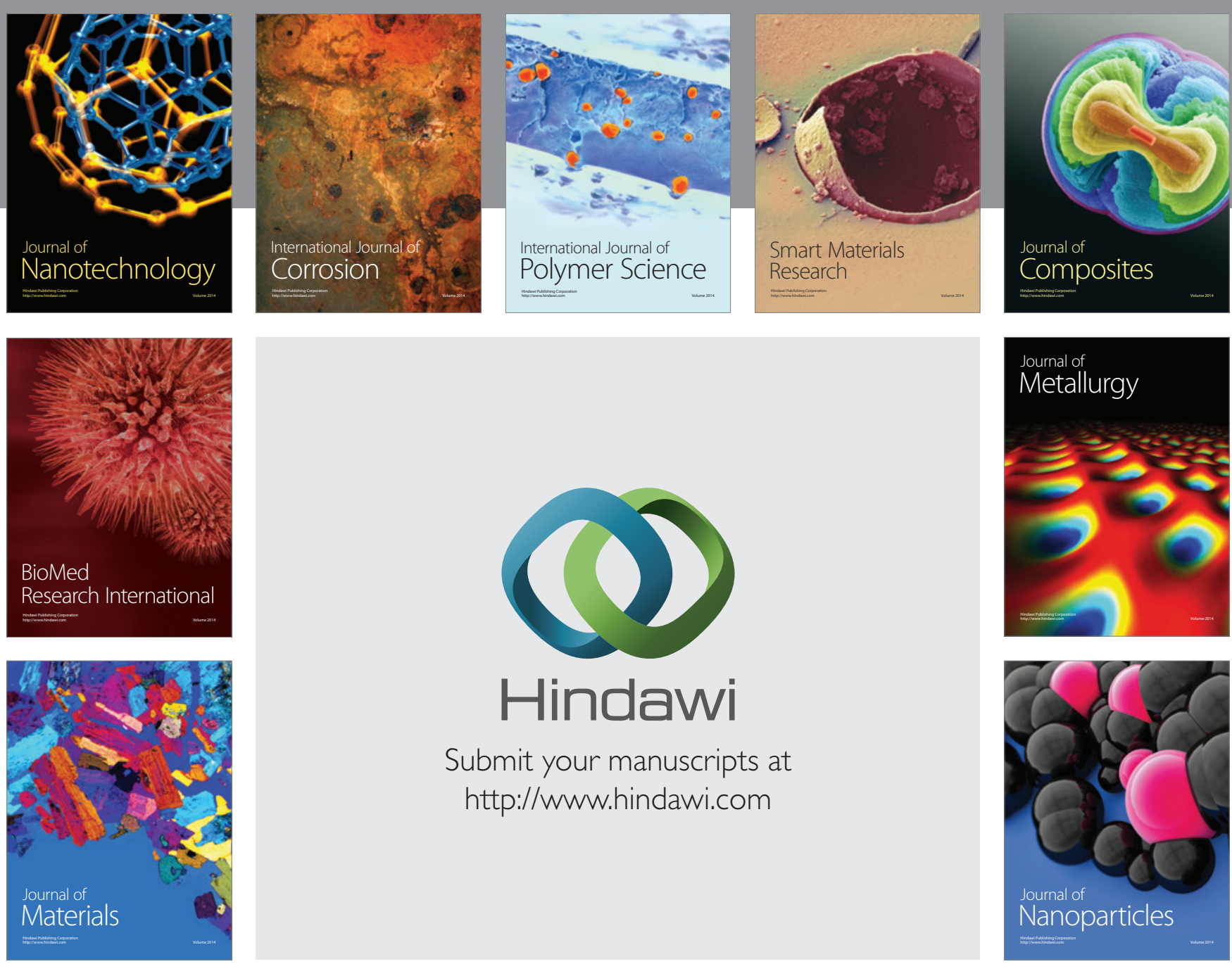

Submit your manuscripts at http://www.hindawi.com
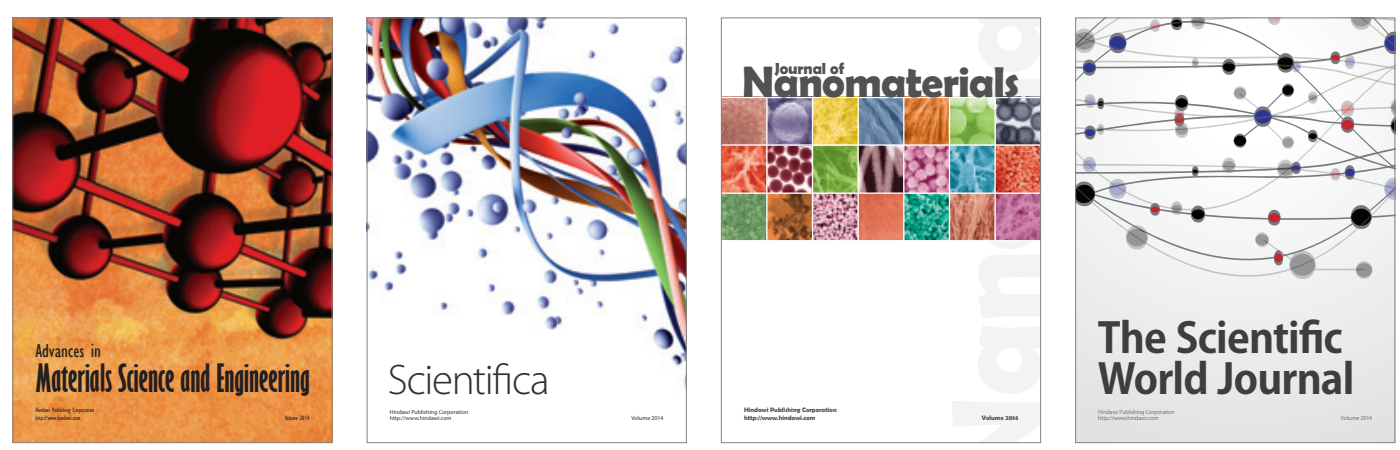

\section{The Scientific World Journal}
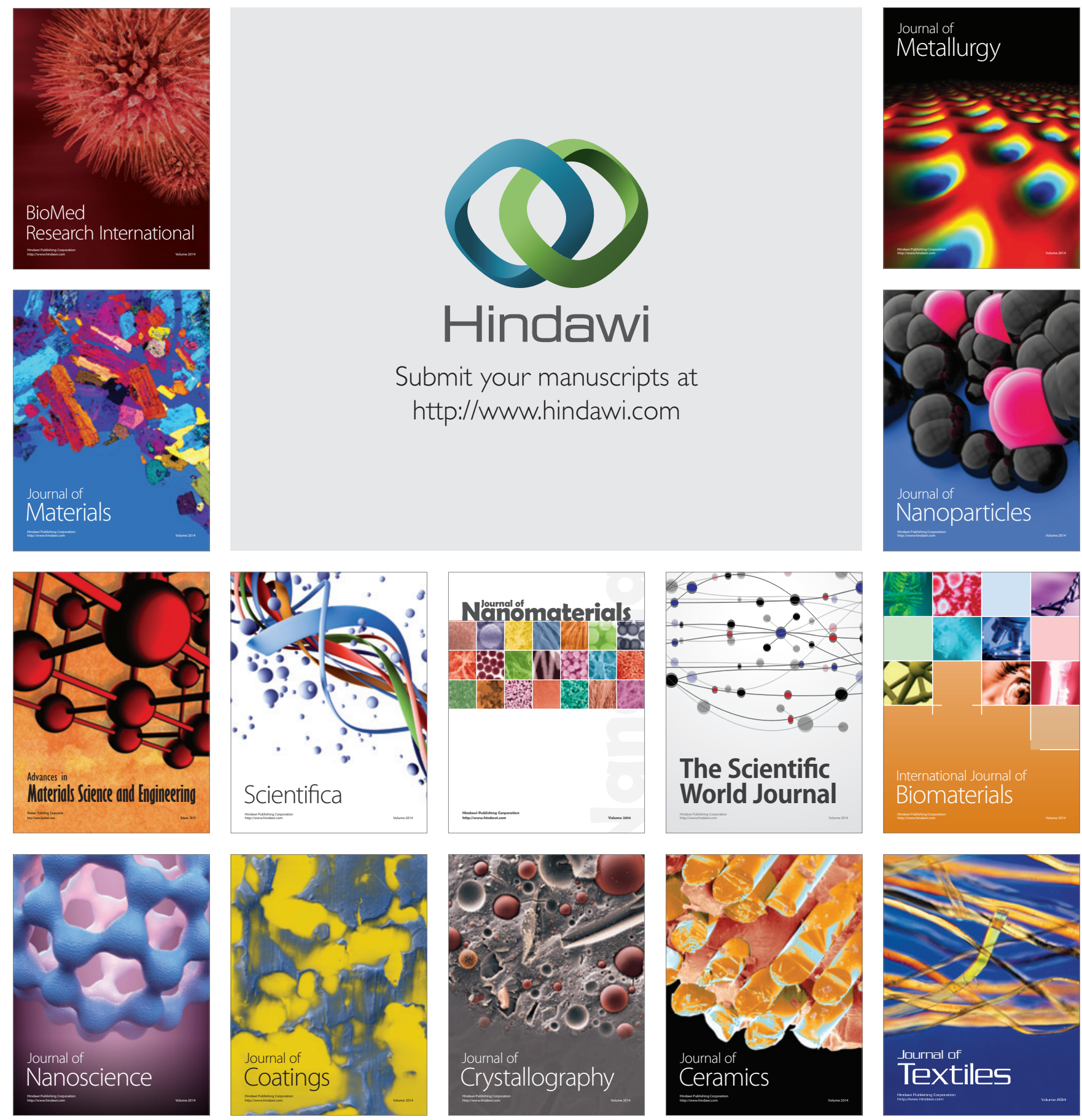